journals", he supplements written sources for modern surveying with interviews with the practitioners themselves, at NASA, the US National Geodetic Survey and so on.

No single volume on the history of cartography can be comprehensive. It is important therefore to note that Wilford's book is really a history of the attempts to measure, survey and map the Earth, the Moon and the planets. The definition of cartography implied in this treatment is that of the United Nations, therefore, and not that of the International Cartographic Association (which excludes survey from its terms of reference). What is particularly valuable is the integration of the historical and the modern. Most histories of mapmaking end in 1900 or earlier, and leave to others the recording of recent developments. Thus the first two parts of the book deal with the broad trends and signal achievements of cartography and geodesy prior to the twentieth century. The final two parts include some earlier history but are focused on the twentieth century.

Another, less welcome, aspect of the treatment is an evident "Western" bias. Like many other histories, the book is "ethno-centred" (to quote the current term), dealing largely with the achievements of Mediterranean and European peoples. Arab geographers such as Idrisi, for example, are conspicuous by their absence, and the remarkable achievements of Chinese cartographers appear only in the pages dealing with the maps from the Ming tombs. In so focusing the story Wilford follows Lloyd A. Brown, whose Story of Maps (Little, Brown; 1949) provided the classic account of mapmaking to 1800 . The similarity in treatment and in the selection of illustrations for the early period explains why some parts of Wilford's book (for example, the sections on the Cassinis and John Harrison) will seem almost familiar to those well acquainted with Brown. Wilford's detailed account of the survey and mapping of India and North America extends the compass, however, in addition to the fact that the time span covered by Wilford is much greater.

The book is illustrated by reproductions of some of the most important maps and by photographs, but documentation of the illustrations is inadequate. The Babylonian world map (p.11), for example, is in the British Museum, not the New York Public Library (p.415), as the reader might suppose from the credits. Sources for information in the text are, for the most part, not cited, but bibliographical notes are provided for each chapter.

In general, however, Wilford's Mapmakers can be warmly recommended as an essential addition to library reference shelves, and as an excellent introduction to mapmaking past and present for geographers and map lovers alike.

Helen Wallis is Map Librarian at The British Library, London.

\title{
Ancient woods in modern times
}

\section{John Andrews}

\begin{abstract}
Woodland Conservation and
Management. By G.F. Peterken. Pp.328. ISBN 0-412-12820-9. (Chapman \& Hall: 1981.) £25, \$49.95. Ancient Woodland: Its History, Vegetation and Uses in England. By Oliver Rackham. Pp.402. ISBN 0-7131-2723-6. (Edward Arnold/University Park Press: 1981.) £50, \$99.95.
\end{abstract}

DURING the past 30 years, more ancient mature woodland has been destroyed in Britain than in the preceding four centuries. The direct cause of this has been the parsimonious attitude of post-War government towards forestry and a corresponding benevolence to agriculture, with an increasingly phoney system of cost-benefit appraisal favouring overproduction from farming while squeezing forestry into short-rotation, softwood monocultures whose main product is pulp.

It is a tribute to the Forestry Commission's technical skill that it has succeeded in developing techniques of wood production under uniquely difficult conditions in the uplands, but no credit to foresters in general that they have fostered the destruction of Britain's remaining native woodlands, both by encouraging their replacement by conifers and by meekly acceding to their conversion to farmland. Perhaps conservationists too must share the blame, for failing to protest sooner and louder: not least the Nature Conservancy Council which should lead the movement, and yet still shies away from producing a policy on forestry after nearly a decade of indecision.

Fortunately, many NCC staff are a good deal harder-nosed than their politicallyappointed Council. Woodland Conservation and Management is written by George Peterken, a member of NCC's scientific team, and ventures some provocative views. Thus,

private landowners, who enjoy a disproportionately large share of national wealth, should be prepared to bear a disproportionately large share of the sacrifices needed to provide national needs for amenity and nature conservation. Indeed, the continued political acceptability of private landowning may depend on recognising these and other public responsibilities

- a view gaining currency among conservationists patronizingly advised to leave protection of the countryside to the good will of the landowning community.

The book, however, is primarily a scientific work. It commences by examining the origins, management and ecological characteristics of British woodland, demonstrating the special value of ancient, primary woodland to a wide range of species which have persisted in such sites - and nowhere else - despite many centuries, perhaps in some cases several millennia, of human management.
The second part of the work considers the types of semi-natural woodland, their classification and management. Woodland classification in Britain is still bedevilled by the lack of a generally accepted system and here the effort is made to present one for use by any competent naturalist or forester. Such a classification has an important practical value, providing the basis for identification of woodland sites of similar type so that comparative conservation and management judgements can be made.

About a third of the book is devoted specifically to woodland nature conservation. There is much helpful advice on the recording and assessment of woodlands and on management methods, both where conservation takes priority and where the first objective is production. Though the emphasis is on native woodlands, the pros, cons and opportunities presented by the new conifer forests in the uplands are not neglected.

The book is well and economically written. Though some sections are technically complex, it contains much of general interest, not least a clear and concise statement of the objectives and priorities of nature conservation - matters on which many foresters and some naturalists seem confused or misinformed. However, as an ornithologist, I must regret the author's heavy botanical bias: though birds have great powers of dispersal, many survive best in ancient woodland; and the absence of any reference to Britain's only endemic bird - the Scottish crossbill, which appears to be largely confined to Caledonian pine forest - cannot be lightly forgiven.

In Ancient Woodland, Oliver Rackham approaches the subject from a different standpoint. In the author's words, the main theme is

the self-renewal typical of English woodland history: the quiet, usually unremarked regrowth of the young shoots, automatically replacing the woods every time they were cut down, decade after decade and century after century.

But it is more than that. Dr Rackham's special skill lies in unravelling man's relationship with woodlands and, in scholarly yet entertaining style, he deduces from them aspects of rural social history since pre-Roman times.

Though the book contains examples from many parts of England and the Continent, it is based largely on the author's own studies in East Anglia. This region is a splendid study area, containing an unusual variety of woods which have been well documented - paradoxically the outcome of early clearance which meant that the remainder assumed special importance for local use and was systematically conserved until recent years. 
Roughly the first quarter of the book covers woodland classification, soils, plant and tree communities; in some measure this overlaps with Peterken but the emphasis on man's role in shaping the woods gives a usefully different slant. Evidence from pollen analysis, soil structure, earthworks and archaeological remains, vegetation and tree rings, oral tradition, paintings and written records is brought together to present woodlands not only as places of beauty, rich in wildlife, but also as a part of our heritage - as much a reflection of past human skills, aspirations and shifts of power as any cathedral.

Moving on to the human uses of woods, the author leads us from Neolithic times through the extensive records of Domesday to

the mad world of the 1970s, in which the price of ordinary oak-trees is as low, in relation to the value of money, as at any time since the fifteenth century; the price of oak timber is higher, again in relative terms, than at any time in history; and prices paid for underwood, provided the seller knows where to find the buyer, seem to be roughly equal to the previous all-time maximum in the eighteenth century.

Nearly half of the text deals with individual tree species, examining their distribution, prehistory and history, modern ecology and conservation. With many references to specific sites, one is presented with the opportunity to go and see for oneself - a temptation I will certainly find irresistible when the sun shines, just as dipping into the book will be a continuing pleasure on rainy days.

John Andrews is Head of Conservation Planning at the Royal Society for the Protection of Birds, Sandy, Bedfordshire.

\section{The malaise of modern medicine?}

\section{Robin Weiss}

The Diseases of Civilisation. By Brian Inglis. Pp.371. ISBN 0-340-21717-0. (Hodder \& Stoughton:1981.) £10.95.

BRIAN Inglis is a respected journalist and author who has written several informative books on the history of medical practice, orthodox, homeopathic and supernatural. His latest, The Diseases of Civilisation, is subtitled "An indictment of traditional methods of medical treatment and a plea for a completely new approach". Inglis surveys the major diseases affecting the Western world today - heart disease, cancer, mental illness, common infections, "auto-immune" and degenerative diseases - and concludes that modern medical science and practice has failed to live up to the high hopes of the immediate post-War period. Rather than question how realistic these expectations ever were, generated by journalists like himself as much as by the medical profession, Inglis concludes that the medical establishment is to blame for the intractability of ill-health in modern times. He depicts the medical profession as a self-perpetuating oligarchy composed of too many narrow specialities which dominates medical education and research, distorting both to serve its own ends and thereby obstructing public health. The food, tobacco and pharmaceutical industries are the accomplices in this medical crime, abetted by Governments that shy away from confrontation with an entrenched medico-industrial complex. Inglis argues that this unholy alliance has prevented the medical profession from embracing and acting upon discoveries of the important roles of diet, stress and other social factors in the causation of disease, so that resources which should be channelled into primary health care are deflected into the ever-increasing expense of high technology hospital treatment.

Much of this argument is regrettably only too true. The medical establishment is extremely conservative and profoundly suspicious of social or "unorthodox" approaches to disease. As Thomas McKeown has long argued, medical education is almost entirely geared to the treatment of acute illness as presented in teaching hospitals; the underlying causes of disease, other than specific pathogens, receive scant attention and the very concept of health is hardly raised during the training of doctors. Governments faced with butter mountains and tobacco revenues usually duck environmental and health issues when confronted by powerful lobbies - witness President Carter dismissing $\mathrm{Mr}$ Califano from the Department of Health, Education and Welfare, and Mrs Thatcher reshuffling Sir George Young out of the Department of Health and Social Security as soon as they tried to take significant action on curbing the promotion of cigarette consumption.

Brian Inglis has tackled a most important subject - the limitations and misconceptions in the modern Western approach to illness and health - yet I find his book disappointing and his message pernicious. Posing as a carefully researched documentary, it is more a polemical tract in the tradition of Ivan Illich's Medical Nemesis in which Inglis overstates his case to the point of being anti-science. His main thesis is that psychosocial stress is not taken into account in the investigation, management and prevention of diseases of civilization. He cites Stewart Wolf's important finding that heart disease hardly occurred in Roseto, Pennsylvania, while the inhabitants maintained a cohesive, conservative society, although they ate a typical Western diet. Wolf himself in Social Environment and Health (University of Washington Press, 1981) views disease as maladaptation to changing social conditions. Inglis concludes that it is therefore wrong to treat disease by orthodox methods. He proceeds to select the failures of modern health care and to ignore all the successes. He would have us believe that all heart surgery is a wasted resource, that no cancer patients benefit from chemotherapy, that mental hospitals should be abolished and that immunization plays little role in preventing infectious diseases. He states that "the net value of orthodox medical treatment is far less than it was twenty-five years ago, and is declining".

The chapters I find most objectionable, no doubt because they deal with my own subjects of study, are on infectious diseases and on cancer. Inglis dismisses research into the identification and control of infectious agents in disease (for example in Legionnaires' disease and in malaria) as "'mechanistic heresy" obscuring psychosocial elements. He also shows a remarkable prejudice against virologists, imagining that they narrowly pursue infectious organisms without reference to epidemiology and pathogenesis. Elsewhere he supposes that virologists have sought to monopolize cancer research, preventing immunologists investigating "cancer immunotherapy", whereas it is the virusinduced cancers that may yield first to immunological means of prevention or therapy. The eradication of smallpox, the resounding medical triumph of the 1970s, is not cited at all in Inglis's book, yet its success depended on the very combination of preventive vaccination and thorough epidemiological investigation that orthodox medicine provided where 2,000 years of ayurvedic methods in India failed. The successful outcome of virological research leading to immunization against poliomyelitis earns a grudging mention, with the extraordinary suggestion that the rare but devastating neurological damage caused by polio virus infection is more related to psychosocial stress than to the virulence of the virus strain. Polio and infectious mononucleosis are two particularly intriguing diseases of civilization in that children of the higher social classes are the ones most at risk; the epidemiological factors underlying this phenomenon are not probed by Inglis, presumably because they do not fit his view of how virologists conduct research.

Inglis's criticisms of orthodox cancer treatment resemble those which have recently occupied the columns of the Washington Post and the diatribe by Dick Richards (The Topic of Cancer: When the Killing Has to Stop; Pergamon, 1982) against those who "cut, burn and poison" 